\title{
Journal of Forensic Research
}

Papp, J Forensic Res 2015, 6:5 DOI: $10.4172 / 2157-7145.1000313$

\section{Social, Ethical and Moral Research about our Society and Culture!}

\section{Zoltan Papp}

Senior Systems Engineer, Diplomat, Miskolc, Hungary

"Corresponding author: Zoltan Papp (Author of pocketFIT), Senior Systems Engineer, Diplomat, Miskolc, Hungary, Tel: +36 30724 4609; E-mail: zoltan.papp@fugeeonline.com

Rec date: September 25, 2015 Acc date: September 26, 2015 Pub date: September 30, 2015

Copyright: (C) 2015 Papp Z. This is an open-access article distributed under the terms of the Creative Commons Attribution License, which permits unrestricted use, distribution, and reproduction in any medium, provided the original author and source are credited.

\section{Opinion}

This study includes camouflaged identities, Origins, predecessors and identities. Many times in my life, people told me that your ethnic origin is determined by the ethnic origin of your mother. For quite a while, I believed these kinds of things but many genetic books and nature's practice seem to state the following:

Your genetic code (DNA), is actually equally determined by both your male and female predecessor! This means that if you are from a mixed ethnic background, then your genetic code (DNA) will be a $>$ new $<$ set of genetic code (DNA). Different from both male and female predecessors, yet, could be similar obviously (Figures 1 and 2). But not necessarily of the same in both motivations, drive or character indeed! Meaning, that you might look similar to your predecessors, but as nature have proved itself in many times before, the motivation, drive and even characters particular to the new-born can vary in larger degrees in fact. In fact, this camouflage effect is employed in nature so much, that many traces can be identified in our history too.

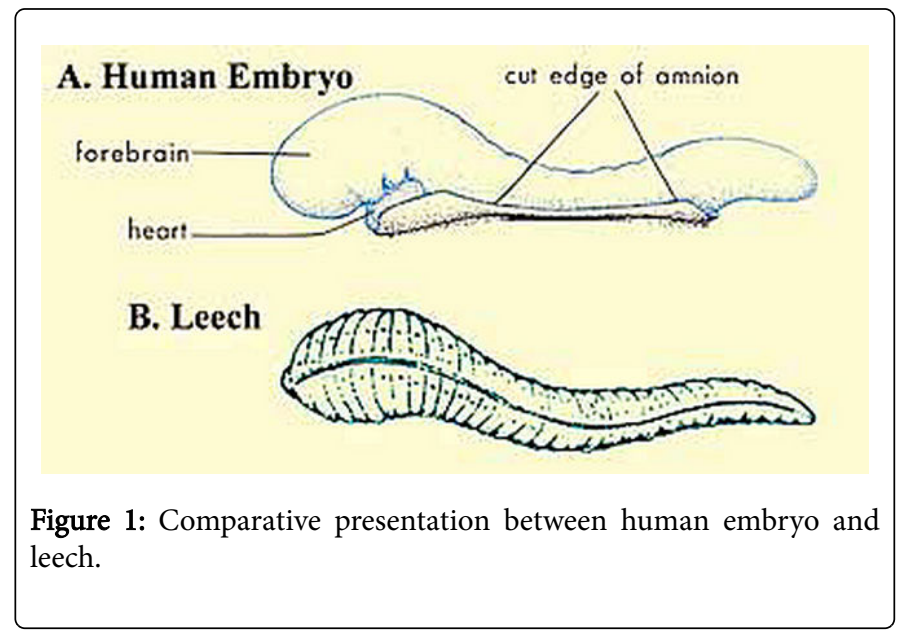

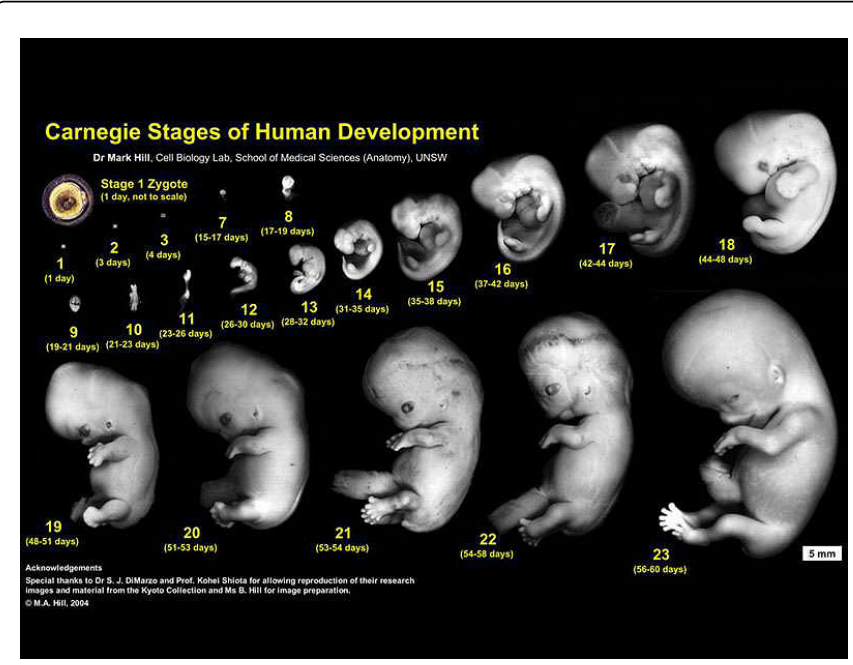

Figure 2: Carnegie stages of human development.

This has led to theological studies of combat between hell and democracy. This is also studied in the Bible and history archives indeed! At first sight, it might not seem important, in reality, it is a well-established practice that less friendly or criminally inclined family members, typically capitalize on depending mavericks of the society. Not meaning old fashioned patronizing of family members, but in more detail, I want to emphasise underground circles where more criminally inclined family members want to capitalize on maverick individuals, who is, in turn, a characterised particular of present day on-going changes in our society!

Islamic state: robbery and fraud by fake replica which was also pointed out several times by President Barack Obama and President candidate, Mr Donald Trump too. Justice is justice. Tempering with the compromise and replica of people's identities is a fundamental violation of law.

The Quran on Human Embryonic Development: http://www.islamguide.com/ch1-1-a.htm (On-line available)

${ }^{*}$ The attached photos are owned by their respective owner! Hope this social, ethical and moral research about our society and culture has helped your work! 